\title{
Službene kontrole u klaonicama
}

Gluščić', Goran, Bela Njari², Nevijo Zdolec², Lidija Kozačinski

\section{SAŽETAK}

Službene kontrole provode se radi provjere pridržavanja propisa o hrani i hrani za životinje te pravila o zdravlju i dobrobiti životinja. Njihova učestalost i opsežnost ovisi o kapacitetu klaonice i analizi rizika a provode ih ovlaštene osobe kontrolnog tijela, ovlašteni veterinari. U ovom su radu prikazani rezultati službenih kontrola u izvoznom klaoničkom objektu registriranom za uslužno klanje papkara i kopitara. Kontrole se provode jednom mjesečno a tijekom godine dana utvrđene su nesukladnosti koje se odnose na higijenu osoblja, prostorija u kojima se rukuje s hranom i higijenu klanja te postupanje s nusproizvodima. Također, uočene su nesukladnosti u postupanju sa životinjama u odnosu na propise o dobrobiti, kao i nedovoljna edukacija djelatnika u tom području. Nesukladnosti su se odnosile i na vođenje dnevnih evidencija. Određene su korektivne mjere koje je subjekt u poslovanju s hranom primijenio i uklonio nesukladnosti u predviđenom roku.

Ključne riječi: službene kontrole, klaonica, nesukladnosti, korektivne mjere

\section{UVOD}

Veterinarstvo je oduvijek bilo sastavnim dijelom preventivne medicine, odnosno primarne zdravstvene zaštite zbog velike uloge u suzbijanju, sprječavanju te iskorjenjivanju zaraznih i parazitarnih zoonoza, te u nadzoru hrane i nastojanjima da se povećaju stočni fond i proizvodnja hrane životinjskog podrijetla, čime se ostvaruju uvjeti pravilne i zdrave prehrane ljudi (Njari i Zdolec, 2012.).

Veterinarsko javno zdravstvo (VJZ) u širem smislu riječi može se definirati kao veterinarska djelatnost u zaštiti zdravlja ljudi ili kao veterinarstvo u zaštiti javnoga zdravstva. U upravnom smislu se VJZ može definirati kao veterinarska djelatnost u provedbi propisa u oblasti veterinarstva i u zdravstvenom nadzoru hrane, posebice s obzirom na zaštitu zdravlja ljudi od bolesti koje se od životinja te njihovih sirovina i proizvoda (hrana životinjskog podrijetla) mogu prenijeti na ljude. Osnovni zadatak VJZ je koordinacija sudjelovanja veterinarstva u praksi javnoga zdravstva i preventivne medicine (Živković, 2001.). U teorijskom, praktičnom i formalnopravnom smislu djelokrug VJZ-a uključuje veterinarske preglede životinja namijenjenih za klaoničku obradu, zatim mesa i ostale hrane životinjskog podrijetla, potom nadzor zoonotskih zaraznih i parazitarnih bolesti, sustavni nadzor ostataka štetnih tvari u životinjama predviđenim za klaoničku obradu i u životinjskim proizvodima, te nadzor nad utilizacijom lešina i otpadnih animalnih tvari u okvirima veterinarske zaštite okoliša (Njari i sur., 2012.).

\section{Kontrolna tijela}

Ministarstvo poljoprivrede, Uprava za veterinarstvo i sigurnost hrane, povjerilo je veterinarskim organi-

1 Goran Gluščić, dr. med. vet., Hrastina Samoborska, Petrova 8, 10430 Samobor

2 Prof. dr. sc. Bela Njari, izv. prof. dr. sc. Nevijo Zdolec, prof. dr. sc. Lidija Kozačinski; Sveučilište u Zagrebu, Veterinarski fakultet, Zavod za higijenu, tehnologiju i sigurnost hrane. Heinzelova 55, Zagreb 
zacijama poslove u okviru službenih kontrola hrane životinjskog podrijetla (kontrolna tijela). Pri tome kontrolna tijela moraju biti nepristrana i ne smiju biti u sukobu interesa pri realizaciji povjerenih poslova, a moraju biti akreditirana u skladu s hrvatskim normama. Kontrolno tijelo obavlja poslove i akreditirano je u skladu s hrvatskom normom o općim zahtjevima za rad različitih vrsta tijela koja provode inspekciju - HRN EN ISO/IEC 17020. Nadležno i kontrolno tijelo moraju koordinirano surađivati, a kontrolno tijelo mora redovito obavještavati nadležno tijelo o rezultatima provedenih kontrola, kao i na zahtjev nadležnog tijela. Kontrolno tijelo o svakoj utvrđenoj nesukladnosti ili njezinoj vjerojatnosti mora unutar 24 sata obavijestiti nadležno tijelo (Mandek, 2013.).

\section{Službene kontrole}

Za provođenje službenih kontrola u području sigurnosti hrane i hrane za životinje, zdravlja i dobrobiti životinja odgovorni su Ministarstvo poljoprivrede te Ministarstvo zdravlja kao nadležna tijela. Službene kontrole provode se u skladu s dokumentiranim procedurama, što je uređeno pomoću Uredbe (EZ) br. 882/2004 o službenim kontrolama koje se provode radi provjere pridržavanja propisa o hrani i hrani za životinje te pravila o zdravlju i dobrobiti životinja. Kako bi olakšalo provođene službenih kontrola Ministarstvo poljoprivrede, Uprava za veterinarstvo i sigurnost hrane, izdalo je Procedure za provođenje službenih kontrola u području sigurnosti hrane i hrane za životinje (Anon., 2014.).

Službene kontrole provode se u skladu s Višegodišnjim nacionalnim planom službenih kontrola, a u pravilu se ne najavljuju osim kada se provodi revizija. Njihova učestalost i opsežnost ovisi ō brojnim čimbenicima i analizi rizika (veličina objekta, vrsta proizvodnje odnosno procesa, rezultati prijašnjih kontrola, sklonost objekta suradnji, pouzdanost sustava samokontrole). Važno je napomenuti da se službene kontrole provode u svim fazama proizvodnje, prerade i distribucije (Anon., 2014.), a provode in ovlaštene osobe koje moraju biti stručne te posjedovati potrebne vještine, biti objektivne i nepristrane, te se držati načela povjerljivosti. Planiranje službenih kontrola veoma je važno zbog njihove učinkovitosti. Prilikom planiranja potrebno je definirati gdje će se (koji SPH) i zašto (njezina svrha) provoditi kontrola. Definira se što (područje i opseg) i kada podliježe kontroli (datum, vrijeme i trajanje), te tko (definirati ovlaštenu osobu koja će provesti kontrolu) i kako (definirati kontrolne metode, tehnike, postupke te potrebnu opremu) provodi kontrolu. Ovlaštena osoba mora sastaviti za- pisnik i sve vezane dokumente i zapise unijeti u bazu podataka nadležnog tijela odnosno nadležnog tijela za provođenje službene kontrole (Anon., 2014.).

Zadaci veterinarske inspekcije u klaoničkim objektima, odnosno provođenje službenih kontrola tema su ovog rada.

\section{MATERIJAL I METODE}

Osnovna djelatnost tvrtke u kojoj je obavljeno istraživanje je uslužno klanje papkara (goveda, svinje, koze, ovce). Klaonički objekt je opremljen modernom klaoničkom opremom i komorama za rashlađivanje mesa, kako bi meso u najkraćem roku bilo spremno za daljnji transport. U tvrtki je uveden HACCP sustav. Klaonica posjeduje EU veterinarski broj što znači da ima pravo plasmana klaoničkih proizvoda unutar EU te u treće zemlje. Kapacitet klaonice je obrada oko 50 grla goveda dnevno. Klaonica je pod stalnim nadzorom veterinarske službe.

Tijekom jednogodišnjeg razdoblja praćene su službene kontrole u klaoničkom objektu. Prema planu službenih kontrola u ovome objektu se kontrole obavljaju jednom mjesečno.

\section{REZULTATI I RASPRAVA}

$\mathrm{U}$ jednogodišnjem periodu prikupljeni su podaci o deset provedenih službenih kontrola. Kroz taj period povremeno su utvrđene manje nesukladnosti koje su prikazane u tablici 1.

Tijekom službenih kontrola provedenih u periodu od godinu dana utvrđen je manji broj nesukladnosti koje smo grupirali ovisno o uzroku njihovog nastajanja, pa je riječ o nesukladnostima vezanima uz osoblje (higijena, stručnost, razina odgovornosti), sam objekt (loša izgradnja, loše projektiranje) i opremu u objektu (neadekvatni materijal, neispravnost opreme).

Kao što je vidljivo iz navoda u Tablici 1., većina utvrđenih nesukladnosti tijekom službenih kontrola u ovom objektu odnosi se na osoblje, njihovo zdravstveno stanje, higijenu, čistoću odjeće, ali i na njihovu odgovornost u stručnom radu. Higijena osoblja predstavlja veliki problem. Nakon određivanja korektivnih mjera na način prikazan u Tablici 1. i razgovora s osobljem, problem je otklonjen. Radnici objekta sada vode više računa o higijeni, a osoblje zaduženo za održavanje sanitarnog prostora obavlja svoj posao češće i kvalitetnije. Upravi objekta ukazana je važnost zdravstvenog stanja osoblja, tj. ukazano je da bolesni radnici ne smiju biti u objektu gdje se radi s proizvodima životinjskog podrijetla zbog moguće kontaminacije proizvoda. Bolesni radnici moraju biti na bolovanju sve dok potpuno ne ozdrave, o čemu postoje liječničke potvrde. Veoma je značajno da SPH shvate kako mesa- 
ri moraju obnavljati svoje znanje o higijenskom minimumu. Naime, Zakon o zaštiti pučanstva od zaraznih bolesti (NN 79/07) obvezuje osobe, koje na svojim radnim mjestima u proizvodnji ili prometu hrane dolaze u dodir s hranom, da moraju imati osnovna znanja o zdravstvenoj ispravnosti hrane i osobnoj higijeni.

Kao što je vidljivo iz podataka u Tablici 1., jedna od navedenih nesukladnosti se odnosila na neispunjavanje evidencija temperature u hladnjači. Određena je korektivna mjera kojom je trebalo odmah pozvati na odgovornost osobu zaduženu za popunjavanje evidencija. Osoblje objekta također nije razumjelo važnost ispunjavanja dnevnih evidencija. Stoga je uprava objekta zajedno s ovlaštenim veterinarom objasnila radnicima zašto je to bitno, te je zadužila odgovornu osobu kako bi se izbjegao najčešći argument osoblja: 'to nije moja dužnost'. Djelatnici moraju biti svjesni da neredovito vođenje evidencije ili bilo koje druge dokumentacije može uzrokovati velike probleme u poslovanju SPH. Poslodavac mora uspostaviti korektan od-

Tablica 1. Rezultati službene kontrole u klaoničkom objektu

\begin{tabular}{|c|c|c|c|c|}
\hline $\begin{array}{c}\text { Službena kontrola/ } \\
\text { datum }\end{array}$ & $\begin{array}{c}\text { Zadovoljavajuće } \\
\text { stanje }\end{array}$ & Utvrđena nesukladnost & Korektivne mjere & Napomena \\
\hline Ožujak 2016. & $\begin{array}{l}\text { Osoblje nosi prikladnu } \\
\text { i čistu radnu odjeću } \\
\text { te ukoliko je potrebno } \\
\text { zaštitne kape, maske, } \\
\text { rukavice i obuću }\end{array}$ & Radna odjeća je prljava. & $\begin{array}{l}\text { Potrebno je više voditi } \\
\text { računa o higijeni osoblja. } \\
\text { - imenovati odgovornu } \\
\text { osobu za održavanje odjeće }\end{array}$ & $\begin{array}{c}\text { SPH je imenovao osobu koja } \\
\text { brine o održavanju odjeće } \\
\text { istoga dana }\end{array}$ \\
\hline Travanj 2016. & $\begin{array}{l}\text { Sanitarni prostor je } \\
\text { čist i održavan }\end{array}$ & Sanitarni prostor je prljav. & $\begin{array}{c}\text { Potrebno je češće i } \\
\text { kvalitetnije održavanje } \\
\text { sanitarnog prostora } \\
\text { - pozvati na odgovornost } \\
\text { osobu zaduženu za čišćenje }\end{array}$ & $\begin{array}{c}\text { SPH je razgovarao s } \\
\text { čistačicom i utvrdio } \\
\text { ponovno dinamiku čišćenja } \\
\text { sanitarnog prostora }\end{array}$ \\
\hline Svibanj 2016. & $\begin{array}{l}\text { Temperatura vode u } \\
\text { sterilizatorima je min. } \\
82^{\circ} \mathrm{C}\end{array}$ & $\begin{array}{l}\text { Temperatura vode } \mathrm{u} \\
\text { sterilizatorima je oko } 60^{\circ} \mathrm{C} \text {. }\end{array}$ & $\begin{array}{c}\text { Potrebno servisirati } \\
\text { sterilizator te uspostaviti } \\
\text { temperaturu od min. } 82^{\circ} \mathrm{C} \text {. } \\
\text { - vremenski rok od } 7 \text { dana }\end{array}$ & $\begin{array}{l}\text { Korektivna mjera je } \\
\text { provedena u vremenu od } \\
\text { tri dana. Postoji potvrda } \\
\text { ovlaštenog servisera. }\end{array}$ \\
\hline Lipanj 2016. & $\begin{array}{l}\text { Osigurana je } \\
\text { adekvatna prirodna ili } \\
\text { umjetna rasvjeta }\end{array}$ & $\begin{array}{l}\text { U manipulativnom hodniku } \\
\text { rasvjeta nije adekvatna - } \\
\text { mračno je. }\end{array}$ & $\begin{array}{l}\text { Potrebno osigurati jaču } \\
\text { rasvjetu. } \\
\text { - vremenski rok od } 7 \text { dana }\end{array}$ & $\begin{array}{l}\text { SPH je pozvao električara } \\
\text { koji je u zadanom } \\
\text { vremenskom roku } \\
\text { promijenio rasvjetno tijelo u } \\
\text { hodniku }\end{array}$ \\
\hline Srpanj 2016. & $\begin{array}{l}\text { Omamljivanje i } \\
\text { iskrvarenje se obavlja } \\
\text { na ispravan način } \\
\text { i bez nepotrebnog } \\
\text { odgađanja }\end{array}$ & $\begin{array}{c}\text { Dolazi do nepotrebnog } \\
\text { odgađanja iskrvarenja jer } \\
\text { omamljivanje i iskrvarenje } \\
\text { provodi ista osoba. }\end{array}$ & $\begin{array}{l}\text { Treba omogućiti dostatan } \\
\text { broj radnika kako } \\
\text { iskrvarenje i omamljivanje } \\
\text { ne bi radila ista osoba. } \\
\text { - vremenski rok od } 1 \text { dana }\end{array}$ & $\begin{array}{l}\text { SPH je pojasnio da su mu } \\
\text { dva radnika na bolovanju te } \\
\text { je došlo do izmjene pozicije } \\
\text { mesara na liniji klanja. } \\
\text { Dogovoreno je da se linija } \\
\text { uspori dok se barem jedan } \\
\text { radnik ne vrati s bolovanja }\end{array}$ \\
\hline Rujan 2016. & $\begin{array}{l}\text { U objektu se vode } \\
\text { propisane dnevne } \\
\text { evidencije koje su } \\
\text { pravilno popunjene }\end{array}$ & $\begin{array}{l}\text { Evidencije nisu popunjene. } \\
\text { Dva puta je propušteno } \\
\text { evidentiranje temperature u } \\
\text { hladnjači }\end{array}$ & $\begin{array}{l}\text { Pozvati na odgovornost } \\
\text { osobu zaduženu za } \\
\text { popunjavanje evidencija. } \\
\text { - vremenski rok odmah }\end{array}$ & $\begin{array}{l}\text { Istoga dana SPH je izrekao } \\
\text { usmenu opomenu osobi } \\
\text { zaduženoj za evidencije }\end{array}$ \\
\hline Listopad 2016. & $\begin{array}{l}\text { Iz prostora za } \\
\text { rukovanje hranom } \\
\text { nusproizvodi se } \\
\text { uklanjaju što je prije } \\
\text { moguće }\end{array}$ & $\begin{array}{c}\text { Spremnici za nusproizvode } \\
\text { su puni te ih nitko ne } \\
\text { uklanja }\end{array}$ & $\begin{array}{l}\text { Potrebno educirati osoblje } \\
\text { o riziku vezanom za } \\
\text { nusproizvode te zadužiti } \\
\text { osobu za taj zadatak. } \\
\text { - vremenski rok od } 3 \text { dana }\end{array}$ & $\begin{array}{l}\text { SPH je zamolio ovlaštenog } \\
\text { veterinara da njegovim } \\
\text { zaposlenicima održi } \\
\text { predavanje o higijenskoj } \\
\text { dispoziciji nusproizvoda } \\
\text { klanja }\end{array}$ \\
\hline Studeni 2016. & $\begin{array}{c}\text { Bolesnim i djelatnicima } \\
\text { sa otvorenim ranama } \\
\text { zabranjen je ulazak u } \\
\text { objekt }\end{array}$ & $\begin{array}{l}\text { Radnik na radnom mjestu } \\
\text { kiše i kašlje, odnosno } \\
\text { pokazuje simptome bolesti }\end{array}$ & $\begin{array}{c}\text { Bolestan radnik ne smije } \\
\text { biti u objektu dok ne preboli } \\
\text { boles. } \\
\text { - vremenski rok odmah }\end{array}$ & $\begin{array}{l}\text { SPH je uputio radnika na } \\
\text { liječnički pregled }\end{array}$ \\
\hline Prosinac 2016. & $\begin{array}{c}\text { Tijekom istovara, } \\
\text { životinje su pošteđene } \\
\text { uznemirenosti, straha, } \\
\text { patnji i bolova }\end{array}$ & $\begin{array}{c}\text { Tijekom istovara životinja } \\
\text { u depo, radnik koristi } \\
\text { prekomjernu silu te } \\
\text { grubim postupanjem } \\
\text { uzrokuje strah, bol i patnju } \\
\text { životinjama }\end{array}$ & $\begin{array}{l}\text { Potrebna je edukacija } \\
\text { radnika o postupanju i } \\
\text { dobrobiti životinja. } \\
\text { - vremenski rok od dva } \\
\text { mjeseca }\end{array}$ & $\begin{array}{c}\text { SPH je uplatio tečaj o } \\
\text { dobrobiti životinja pri } \\
\text { usmrćivanju koji organizira } \\
\text { HVK koji su pohađala } \\
\text { dva radnika (priloženi su } \\
\text { certifikati) }\end{array}$ \\
\hline Ožujak 2017. & $\begin{array}{l}\text { Životinje su pravilno } \\
\text { omamljene prije } \\
\text { iskrvarenja }\end{array}$ & $\begin{array}{c}\text { Radnik zadužen za } \\
\text { omamljivanje drži elektrode } \\
\text { nepotrebno dugo na } \\
\text { životinji }\end{array}$ & $\begin{array}{l}\text { Potrebno je educirati } \\
\text { radnika kako bi } \\
\text { omamljivanje provodio } \\
\text { stručno. } \\
\text { - vremenski rok od dva } \\
\text { mjeseca }\end{array}$ & $\begin{array}{l}\text { SPH je pojasnio da je radnik } \\
\text { na zamjeni a nije pohađao } \\
\text { tečaj. Radnik koji ima } \\
\text { potvrdu o edukaciji uputio } \\
\text { ga je odmah u tehniku } \\
\text { omamljivanja, a mesar je } \\
\text { prijavljen na tečaj }\end{array}$ \\
\hline
\end{tabular}


nos s djelatnicima ali i način kontrole njihovog rada. Pri rješavanju ove nesukladnosti SPH je imenovao odgovornu osobu za vođenje evidencije, što možda nije najspretnije rješenje, no tako je spriječio radnike da izbjegavaju obavljanje određenih „papirnatih“ poslova kojima nisu skloni.

Sljedeća je nesukladnost utvrđena u postupku klaoničke obrade. Naime, nusproizvodi nisu otklanjani pravovremeno što je predstavljalo potencijalan rizik za higijensku ispravnost i kakvoću mesa. Kako bi osoblje objekta bolje razumjelo problematiku te pravovremeno odvozilo nusproizvode životinjskog podrijetla iz prostorije za klaoničku obradu, ovlašteni veterinar je održao edukaciju osoblja na tu temu. Osoblje je nakon toga imalo više informacija, te su se nusproizvodi počeli odvoziti pravovremeno.

Što se samog objekta tiče, glavna zamjerka odnosila se na osvjetljenje manipulativnog hodnika, rasvjeta je bila preslaba. Naređeno je da u roku od 7 dana treba pojačati rasvjetu što je SPH i napravio. Od opreme

Table 1. Results of the official checkup in the slaughterhouse

\begin{tabular}{|c|c|c|c|c|}
\hline $\begin{array}{l}\text { Official checkup/ } \\
\text { date }\end{array}$ & Satisfying condition & $\begin{array}{l}\text { Determined non- } \\
\text { compliance }\end{array}$ & Corrective measures & Note \\
\hline March 2016 & $\begin{array}{l}\text { The staff wear } \\
\text { suitable and clean } \\
\text { work clothes and if } \\
\text { necessary, protective } \\
\text { caps, masks, gloves } \\
\text { and footwear }\end{array}$ & Work clothes are dirty & $\begin{array}{l}\text { It is necessary to take more } \\
\text { care about the hygiene } \\
\text { of the staff - a person } \\
\text { responsible for clothes } \\
\text { maintenance should be } \\
\text { appointed }\end{array}$ & $\begin{array}{l}\text { The same day SPH appointed a } \\
\text { person who will take care about } \\
\text { the maintenance of the clothing. }\end{array}$ \\
\hline April 2016 & $\begin{array}{l}\text { Sanitary areas are } \\
\text { clean and maintained }\end{array}$ & Sanitary areas are dirty & $\begin{array}{l}\text { Sanitary areas should be } \\
\text { more often and better } \\
\text { cleaned } \\
\text { - a person responsible for } \\
\text { cleaning should be called }\end{array}$ & $\begin{array}{l}\text { SPH talked to a cleaning lady } \\
\text { and re-established a dynamics of } \\
\text { cleaning sanitary areas }\end{array}$ \\
\hline May 2016 & $\begin{array}{l}\text { Water temperature in } \\
\text { sterilizers is min. } 82^{\circ} \mathrm{C}\end{array}$ & $\begin{array}{c}\text { Water temperature } \\
\text { in sterilizers is about } \\
60^{\circ} \mathrm{C} \text {. }\end{array}$ & $\begin{array}{l}\text { The sterilizer should be } \\
\text { serviced and a minimum } \\
\text { temperature of } 82^{\circ} \mathrm{C} \text { should } \\
\text { be established. } \\
\text { - Time period } 7 \text { days }\end{array}$ & $\begin{array}{l}\text { The corrective measure was } \\
\text { carried out within three days. } \\
\text { There is a certificate of the } \\
\text { authorized servicer. }\end{array}$ \\
\hline June 2016 & $\begin{array}{l}\text { Adequate natural or } \\
\text { artificial lighting has } \\
\text { been ensured }\end{array}$ & $\begin{array}{l}\text { The lighting in the } \\
\text { manipulation corridor is } \\
\text { not adequate. It is dark. }\end{array}$ & $\begin{array}{c}\text { Better lighting should be } \\
\text { ensured - time period of } 7 \\
\text { days }\end{array}$ & $\begin{array}{l}\text { SPH called an electrician who } \\
\text { changed a luminaire within the } \\
\text { requested time period }\end{array}$ \\
\hline July 2016 & $\begin{array}{l}\text { Stunning and bleeding } \\
\text { out are performed in } \\
\text { a correct way without } \\
\text { unnecessary delay }\end{array}$ & $\begin{array}{l}\text { There is unnecessary } \\
\text { delay of bleeding } \\
\text { out as stunning and } \\
\text { bleeding out are } \\
\text { performed by the } \\
\text { same person. }\end{array}$ & $\begin{array}{l}\text { A sufficient number of } \\
\text { workers should be ensured } \\
\text { so that bleeding out and } \\
\text { stunning are not performed } \\
\text { by the same person } \\
\text { - a time period } 1 \text { day }\end{array}$ & $\begin{array}{l}\text { SPH explained that two workers } \\
\text { are on sick leave and that butchers } \\
\text { for slaughtering were changed. It } \\
\text { was agreed to slow down the line } \\
\text { until at least one worker comes } \\
\text { back from sick leave. }\end{array}$ \\
\hline September 2016 & $\begin{array}{l}\text { Properly filled in } \\
\text { records are kept at the } \\
\text { building }\end{array}$ & $\begin{array}{l}\text { Records are not filled } \\
\text { in. The temperature in } \\
\text { a cold storage has not } \\
\text { been recorded twice }\end{array}$ & $\begin{array}{l}\text { A person responsible for } \\
\text { filling in the records must be } \\
\text { held accountable } \\
\text { - time period - immediately }\end{array}$ & $\begin{array}{c}\text { SPH gave a verbal warning to the } \\
\text { person in charge of records on } \\
\text { the same day }\end{array}$ \\
\hline October 2016 & $\begin{array}{l}\text { By-products are } \\
\text { removed from the } \\
\text { food handling area as } \\
\text { soon as possible }\end{array}$ & $\begin{array}{l}\text { By-product containers } \\
\text { are full and nobody } \\
\text { has removed them }\end{array}$ & $\begin{array}{l}\text { The staff have to be } \\
\text { educated about the risks } \\
\text { related to by-products and a } \\
\text { person has to be appointed } \\
\text { for that task. } \\
\text { - time period - } 3 \text { days }\end{array}$ & $\begin{array}{l}\text { SPH asked an authorised vet to } \\
\text { give a lecture to its employees } \\
\text { about the hygiene disposition of } \\
\text { slaughtering by-products }\end{array}$ \\
\hline November 2016 & $\begin{array}{l}\text { Sick employees and } \\
\text { employees with open } \\
\text { wounds are forbidden } \\
\text { to enter the building }\end{array}$ & $\begin{array}{l}\text { A worker at his } \\
\text { workplace is sneezing } \\
\text { and coughing, i.e. has } \\
\text { symptoms of a disease }\end{array}$ & $\begin{array}{c}\text { A sick worker must not } \\
\text { be in the building until he } \\
\text { recovers } \\
\text { - time period - immediately }\end{array}$ & $\begin{array}{l}\text { SPH sent a worker for a medical } \\
\text { examination }\end{array}$ \\
\hline December 2016 & $\begin{array}{c}\text { During unloading, } \\
\text { animals are spared of } \\
\text { distress, fear, suffering } \\
\text { and pain }\end{array}$ & $\begin{array}{l}\text { During unloading of } \\
\text { animals into a depot, a } \\
\text { worker uses excessive } \\
\text { force and with his } \\
\text { rough handling causes } \\
\text { fear, pain and suffering } \\
\text { to animals }\end{array}$ & $\begin{array}{l}\text { Workers should be } \\
\text { educated about handling } \\
\text { and welfare of animals. } \\
\text { - time period of two months }\end{array}$ & $\begin{array}{l}\text { SPH paid a course on animal } \\
\text { welfare during killing organizes by } \\
\text { HVK which was attended by two } \\
\text { workers (certificates enclosed) }\end{array}$ \\
\hline March 2017 & $\begin{array}{l}\text { Animals are properly } \\
\text { stunned before } \\
\text { bleeding out }\end{array}$ & $\begin{array}{l}\text { A worker in } \\
\text { charge of stunning } \\
\text { keeps electrodes } \\
\text { unnecessary long on } \\
\text { an animal }\end{array}$ & $\begin{array}{l}\text { A worker should be } \\
\text { educated how to perform } \\
\text { stunning in a professional } \\
\text { manner. } \\
\text { - time period - } 2 \text { months }\end{array}$ & $\begin{array}{l}\text { SPH made clear that it was a } \\
\text { substitute worker who had } \\
\text { not attended a course. A } \\
\text { worker who has a certificate on } \\
\text { education instructed him about } \\
\text { the stunning technique and a } \\
\text { butcher applied for a course }\end{array}$ \\
\hline
\end{tabular}


koja se koristi u objektu, utvrđeno je da je sterilizator noževa bio neispravan. Voda u njemu mora biti zagrijana na najmanje $83^{\circ} \mathrm{C}$, dok je u stvarnosti izmjereno $62{ }^{\circ} \mathrm{C}$, što je neprihvatljivo jer se gubi uloga sterilizatora. Sterilizator je poslan na servis te je kvar otklonjen u kratkom roku.

SPH trebaju inzistirati na edukaciji svojih djelatnika u području dobrobiti životinja pri usmrćivanju. Svakako treba imati na umu da bi bilo poželjno da, kada je riječ o manjim objektima, tečaj završe barem dva djelatnika.

Sve nesukladnosti navedene u Tablici 1. morale su se ispraviti u roku koji je određen pri samoj službenoj kontroli. Ovisno o težini nesukladnosti, ovlašteni je veterinar odredio i korektivne mjere. Korektivne su se mjere morale primijeniti odmah (poput razgovora s pomoćnim osobljem, čistačicama oko održavanja higijene sanitarnih prostora i održavanja radne odjeće mesara) ili najdulje kroz dva mjeseca (primjer su mjere koje se odnose na edukaciju mesara, a vezane su na termine održavanja tečajeva potrebnih za dobro obavljanje poslova).

Jesu li mjere provedene kako treba, prema postupku kontrolnog tijela koje je nadležno za predmetnu klaonicu, provjerava ovlašteni veterinar. Mogli bismo reći da je tijekom godine dana obavljanja službenih kontrola u objektu utvrđen manji broj nesukladnosti koje su se mogle otkloniti veoma brzo i mogli bismo ih nazvati "lakšim nesukladnostima". Sve korektivne mjere koje su naređene provjerava odgovorna osoba, a u našem je slučaju to bio ovlašteni veterinar.

Kao što smo već ranije spomenuli, ono što nedostaje u propisima je realnije određena učestalost službenih kontrola. Na taj se problem osvrnuo i Ivan Forgač, dr. med. vet., predsjednik Hrvatske veterinarske komore u svom uvodnom izlaganju „Veterinarstvo - stanje i prioriteti" na 6 . veterinarskom kongresu u Opatiji 2016. godine. Forgač (2016) ističe konstantno smanjenje učestalosti službenih kontrola. Smatra da se učestalost ne određuje na osnovu kvalitetne analize rizika nego se podređuje količini novčanih sredstava. Razloge za tu tvrdnju nalazi u činjenici da su prihvaćene minimalne pristojbe koje SPH uplaćuju u Državni proračun, pa se pod izgovorom da sredstva za financiranje službenih kontrola nisu dostatna za kvalitetnu kontrolu hrane od polja do stola smanjuje učestalost službenih kontrola. Forgač (2016) naglašava da se istovremeno, dok nadležne službe smanjuju učestalost službenih kontrola povećava broj "plutajućih goveda", siva ekonomija u sferi prometa životinja, klanja životinja, proizvodnje i prometa proizvoda životinjskog podrijetla, a kontrole uvezene hrane uopće ni nema. Jedan dio službenih kontrola preuzimaju dr- žavni inspektori. Navodeći još neke propuste u provođenju službenih kontrola autor ističe da se s obzirom na navedeno, postavlja pitanje funkcioniranja veterinarskih organizacija koje imaju status kontrolnog tijela. Smatra da navedeno smanjenje cijena službenih kontrola i konstantno smanjenje učestalosti obavljanja službenih kontrola kontrolna tijela dovode do toga da se od naknada za službene kontrole ne mogu pokriti svi troškove njihovog obavljanja.

\section{ZAKLJUČCI}

Službene kontrole u klaonicama regulirane su propisima, a provode se različitom dinamikom, ovisno o kapacitetu objekta. Kontrole provode ovlaštene osobe kontrolnog tijela, ovlašteni veterinari. Klaonica u kojoj su provedene službene kontrole tijekom jedne godine registrirana je za obavljanje uslužnih klanja papkara, te je pod stalnim nadzorom veterinarske službe. Službene se kontrole obavljaju prema unaprijed utvrđenoj dinamici, jednom mjesečno. Rezultati službenih kontrola pokazali su da su tijekom jednogodišnjeg perioda utvrđene manje nesukladnosti koje se odnose na osoblje (zdravstveno stanje, higijena, stručnost i odgovornost pri obavljanju poslova), objekt (održavanje sanitarnih prostora, neodgovarajuća rasvjeta) i opremu u objektu (neispravna oprema, sterilizatori za noževe). Određene korektivne mjere SPH je uklonio na vrijeme, što je provjerio ovlašteni veterinar. Na koncu možemo zaključiti da većina nesukladnosti proizlazi zbog nedovoljne edukacije mesara i pomoćnog osoblja, ali i nepravovremene reakcije SPH na nepravilnosti u radu djelatnika.

* Rad je izvadak iz diplomskog rada Gluščić Goran (2017): Službene kontrole u klaonicama. Diplomski rad. Veterianrski fakultet Sveučilišta u Zagrebu, rukopis str. 46 (mentor: prof. dr. sc. Lidija Kozačinski)

\section{LITERATURA}

Anonimno (1992): Pravilnik o uvjetima kojima moraju udovoljavati objekti za klanje životinja, obradu, preradu i uskladištenje proizvoda životinjskog podrijetla (NN broj 20/1992)

Anonimno (2007): Zakon o zaštiti pučanstva od zaraznih bolesti (NN 79/07)

Anonimno (2014): Procedure za provođenje službenih kontrola u području sigurnosti hrane i hrane za životinje. Uprava za veterinarstvo i sigurnost hrane, Ministarstvo poljoprivrede

Anonimno (2016): Zapisnik s Godišnje skupštine Hrvatske veterinarske komore Veterinarski fakultet, 6. listopada 2016. (Klasa: 322-01/15-01/315 Ur. br.: 312-16-2, Zagreb, 18. listopada 2016.) Hrvatski veterinarski vjesnik, 24, 7-8, str. 7-22

Forgač, I. (2016): Veterinarstvo - stanje i prioriteti. Izlaga- 
nje sa 6. veterinarskog kongresa Opatija, 26.-29. listopada 2016. http://veterina.com.hr/?p=57997 (pristupljeno 5.5.2017.).

Mandek, S. (2013): Kontrolna tijela - organizacija službenih kontrola u Republici Hrvatskoj. Uprava za veterinarstvo i sigurnost hrane, Ministarstvo poljoprivrede. http://veterina.com. $\mathrm{hr} / \mathrm{p} \mathrm{p}=24142$ (pristupano, veljača 2017.)

Njari, B., N. Zdolec (2012): Klaonička obrada i veterinarski pregled. Veterinarski fakultet, Zagreb.

Njari, B., B. Mioković, L., Kozačinski, ž. Cvrtila Fleck, N., Zdolec (2012): Higijena i tehnologija hrane. U: Veterinarsko javno zdravstvo i sigurnost hrane. Ur. Njari B., Kozačinski L., Cvrtila
Fleck Ž. Veterinarski fakultet Sveučilišta u Zagrebu, Zagreb.

Živković, J. (2001): Higijena i tehnologija mesa. I. dio. Veterinarsko-sanitarni nadzor životinja za klanje i mesa (II. dopunjeno izdanje). pripremio i dopunio M. Hadžiosmanović., Veterinarski fakultet Sveučilišta u Zagrebu. „Orbis“ Zagreb.

* Uredba (EZ) br. 882/2004 Europskog parlamenta i Vijeća od 29. travnja 2004. o službenim kontrolama koje se provode radi provjeravanja poštivanja propisa o hrani i hrani za životinje te propisa o zdravlju i dobrobiti životinja (SL L 165, 30. 4. 2004)

Dostavljeno: 7.3.2018.

Prihvaćeno: 26.4.2018.

\section{Official controls in slaughterhouses}

\section{SUMMARY}

Official controls are performed to ensure the verification of compliance with feed and food law, animal health and animal welfare rules. Frequency and broadness of official controls depend on size of slaughterhouse and proper risk analysis. Official controls are carried out by the competent authorities, Official Veterinarians.

In this diploma thesis, we present data from official controls carried out in export slaughterhouse registered for even-toed and odd-toed animals slaughtering. Official controls in this slaughterhouse carry out once per month and during a 12-month period we identified some non-compliances. Non-compliances identified in slaughterhouse referred to: personnel hygiene, slaughter hygiene, meat manipulation hygiene, condemned meat and offal disposal. Personnel also showed lack of knowledge related to animal welfare rules and aversion to daily evidence fulfilment.

Corrective measures and deadline for implementation were defined. Slaughterhouse successfully fulfilled all the requirements within demanded deadline.

Key words: offical control, slaughterhouse, non-compliances, corrective measures

\section{Amtliche Kontrollen in Schlachthöfen}

\section{ZUSAMMENFASSUNG}

Amtliche Kontrollen werden durchgeführt, um die Einhaltung der Lebensmittel- und Futtermittelgesetze sowie der Regeln für die Gesundheit und das Wohlergehen der Tiere zu überprüfen. Ihre Häufigkeit und ihr Umfang hängen von der Kapazität des Schlachthofs und der Risikoauswertung aus; sie werden von autorisierten Vertretern der Kontrollbehörde, bzw. autorisierten Tierärzten durchgeführt. In dieser Arbeit sind die Ergebnisse der amtlichen Kontrollen in einem Exportschlachthof dargestellt, der für das Schlachten von Paarhufern und Equiden registriert ist. Die Kontrollen werden einmal monatlich durchgeführt. Im Laufe eines Jahrs wurden Abweichungen festgestellt, die sich auf die Hygiene des Personals, der Räumlichkeiten, in denen mit Nahrungsmitteln umgegangen wird, des Schlachtens sowie den Umgang mit Nebenerzeugnissen beziehen. Es wurden darüber hinaus Abweichungen beim Umgang mit den Tieren in Bezug auf die Vorschriften über das Wohlergehen der Tiere sowie eine mangelnde Schulung der Angestellten in diesem Bereich festgestellt. Die Abweichungen bezogen sich auch auf das Führen von Tagesbüchern. Es wurden Nachbesserungsmaßnahmen bestimmt, welche vom Schlachthof umgesetzt wurden, womit die Abweichungen in der vorgesehenen Frist beseitigt wurden.

Schlüsselwörter: amtliche Kontrollen, Schlachthof, Abweichungen, Nachbesserungsmaßnahmen 


\section{Controles oficiales en los mataderos}

\section{RESUMEN}

Se están haciendo controles oficiales para verificar el cumplimiento de los reglamentos sobre los alimentos y piensos y las normas de salud y bienestar de los animales. Su frecuencia y su alcance dependen de la capacidad del matadero y del análisis de riesgo que llevan a cabo las personas autorizadas dentro de los organismos de control, es decir los veterinarios autorizados. En este trabajo fueron demostrados los resultados de los controles oficiales en el matadero de exportación para el servicio de matanza de los artio dáctilos y ungulares. Los controles se llevan al cabo una vez por mes y durante un año fueron determinadas las disconformidades en relación con la higiene del personal, de las salas para la manipulación de alimentos, la higiene de matanza y el manejo de subproductos. También había una disconformidad en el trato de los animales en relación con las normas de bienestar y la educación insuficiente de los empleados en este campo. Las disconformidades se refirieron también al mantenimiento de los registros diarios. Se habían determinado las medidas correctivas que la entidad en el negocio de los alimentos aplicó y eliminó las disconformidades dentro del límite de tiempo prescrito.

Palabras claves: controles oficiales, matadero, disconformidades, medidas correctivas

\section{Attività ispettiva nelle macellerie}

\section{RIASSUNTO}

L'attività ispettiva viene posta in essere per verificare il rispetto della normativa che disciplina la sicurezza alimentare, la qualità del mangimi e la salute e il benessere degli animali. La frequenza e la portata di tale attività ispettiva dipende dalla capacità produttiva delle macellerie e dall'analisi dei rischi. Essa è affidata al personale autorizzato dell'organo di controllo, composto da medici veterinari qualificati. In questo studio sono illustrati i risultati delle ispezioni effettuate in un impianto di macellazione per l'esportazione registrato per prestare servizi di macellazione di artiodattili e ungulati. I controlli sono svolti una volta al mese. In un anno sono state accertate varie irregolarità che riguardano l'igiene del personale e dei locali nei quali awiene la manipolazione del cibo, l'igiene del processo di macellazione e il trattamento dei sottoprodotti. Sono state anche riscontrate difformità nel trattamento degli animali rispetto alla normativa che ne disciplina la salute e il benessere, ma anche, sotto quest'aspetto, una certa insufficienza nell'educazione del personale. Difformità sono state riscontrate anche nella tenuta delle evidenze giornaliere. Sono state disposte misure correttive che il soggetto interessato, operante nell'industria alimentare, ha adottato, rimuovendo cosi le difformità entro il termine previsto.

Parole chiave: ispezioni, macelleria, difformità, misure correttive

\section{Međunarodni kongres nutricionista}

\section{- 6. Međunarodni kongres nutricionista se održati} će se od 26. do 28. listopada 2018. godine u Zagrebu. Naime, već šestu godinu za redom uspješno organiziramo Međunarodni kongres nutricionista, koji ove godine po prvi puta organizira Hrvatski Savez Nutricionista- nacionalna zajednica udruga nutricionista i dijetetičara u Republici Hrvatskoj. Međunarodni kongres nutricionista je poseban po tome što okuplja ne samo nutricioniste već i stručnjake razlicitih grana znanosti od medicine, farmacije, kineziologije, psihologije, prehrambene tehnologije do agronomije. Sudjelovanje na Kongresu redovito je bodovano od strane strukovnih komora Republike Hrvatske te ga posjeti preko 400 sudionika iz Hrvatske i inozemstva. Kongres je koncipiran kroz niz predavanja, radionica, panel i sponzoriranih predavanja gdje će stručnjaci iz različitih polja djelovanja iznijeti i obrazlagati najnovija znanstvena saznanja i aktualnosti povezanih s nutricionizmom kao znanosti, nutricionizmom kao dijelom procesa liječenja, ali i dijelom životnog užitka i održivog razvoja.

Osim znanstveno-poslovnog dijela, program Kongresa bogat je i društvenim događanjima te ćemo slobodno vrijeme imati ispunjeno interaktivnim eno-gastro eventom, edukativnim izletima, a vrhunac zabave je uvijek tradicionalno druženje na Gala večeri.

Promocija zdravog življenja predmet je zanimanja sve većeg broja ljudi, ne samo na individualnoj nego i na globalnoj razini zbog čega ovoj temi i mediji posvećuju veliku pažnju, stoga će i 6 . Međunarodni kongres nutricionista biti iznimno medijski popraćen. Nadamo se da ćete prepoznati potencijal 6. Međunarodnog kongresa nutricionista i uvidjeti zajednički interes te Vas pozivamo da nam se pridružite kako bi na zadovoljstvo svih nas ovogodišnji Kongres nadmašio prethodne. 